\title{
EXFOLIATIVE CYTOLOGY OF THE INTUBATED LARYNX IN CHILDREN"
}

\author{
Oscar Farmati, m.D., J. R. Quinn, M.D., and R. H. Fennell, Jr., M.d. $\dagger$
}

REPORTS OF SEQUELAE following endotracheal intubation initially appearing in the literature are characteristically in terms of gross consequences lending themselves to clinical classification. ${ }^{1-3}$ Recent studies involve histologic changes and consequently utilize animal or post-mortem material. This is a study using cytologic evidence of injury to the respiratory epithelium obtained from selected cases in man at the time of extubation.

\section{METHOD}

Patients ranged in age from six months to ten years. A history of recent respiratory infection, evident nasopharyngeal congestion, or the suspicion of trauma during intubation excluded the patient from the series. Preoperative medication included atropine approximately $0.1 \mathrm{mg}$. per 10 pounds of body weight. Anaesthesia consisted of $\mathrm{N}_{2} \mathrm{O}-\mathrm{O}_{2}$-halothane. The endotracheal tubes were uncuffed For-Clear ${ }^{*}$ plastic tubes. The required size was estimated by using the French scale, and tubes were chosen equal in numerical size to the age of the patient plus twenty. The length of each tube was related to the diameter according to the scale of Marcy intended to produce a very short tube. ${ }^{4}$ The tubes were gas sterilized.

Seventy patients were finally considered for evaluation. No lubricant was used on the tube in 50 patients. In the remaining 20 a thin layer of Xylocaine 5 per cent water soluble ointment was applied to the tube, and the larynx was sprayed using a Cordner needle and the volume of Xylocaine 2 per cent solution that would contain $1 \mathrm{mg}$. of drug per pound of body w'eight.

The larynx was visualized with a laryngoscope and straight blade following the administration of succinylcholine intravenously or during deep planes of anaesthesia. The slide preceding intubation was prepared with a dry cotton applicator applied gently to the posteromedial aspect of the right vocal cord under direct visualization. A second slide was prepared similarly from the left vocal cord following extubation. The duration of anaesthesia varied from 20 to 200 minutes, during which a variety of otologic and ocular procedures were completed. No suction was applied to the airway preceding extubation. Each smear was immediately coated with Spray-Cyte ${ }^{\circledR}$ fixative and later Papanicolaou staining was applied. ${ }^{5}$

"From the Departments of Anesthesiology and Pathology, University of Pittsburgh School of Medicine, and Eye and Ear Hospital, Pittsburgh, $\mathrm{Pa}$,

†Dr. Farmati is Instructor, Department of Anesthesiology, and Clinical Research Associate, Department of Pharmacology, University of Pittsburgh. Dr. Quinn is Clinical Assistant Professor, Department of Anesthesiology, University of Pittsburgh School of Medicine, and Director of the Department of Anesthesiology, Eye \& Ear Hospital, Pittsburgh. Dr. Fennell is Professor of Pathology, University of Pittsburgh School of Medicine. 


\section{Results}

The preintubation smear consisted of epithelial cells of squamous and columnar type, histiocytes and rare neutrophils. Mucus was present in some areas as a bluish background. Squamous cells of the superficial and intermediate type were the predominant epithelial cells. The columnar type cells tended to be ovoid, and cilia were difficult to see. Bacteria were occasionally present (Fig. 1).

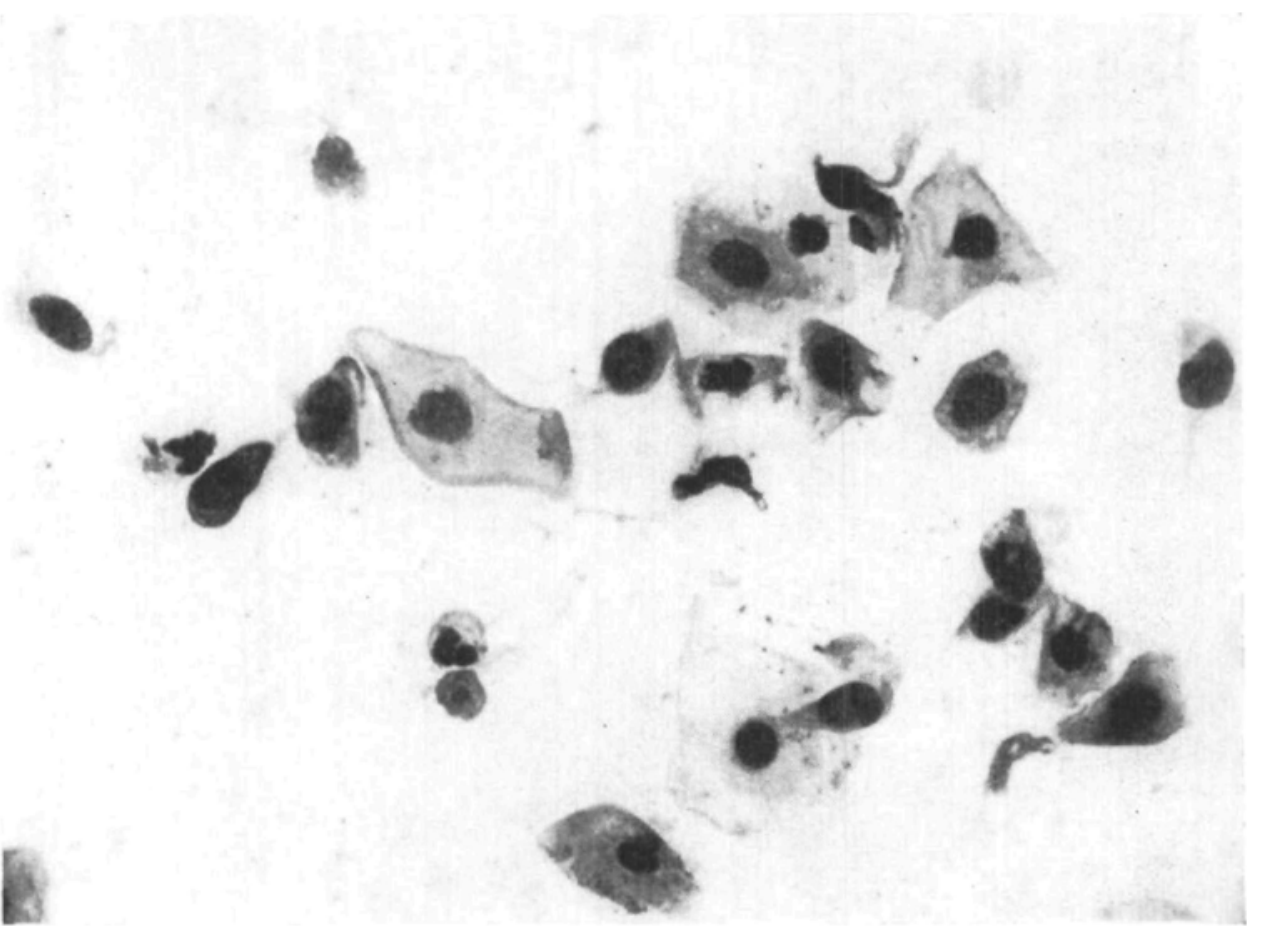

Ficune 1. Papanicolaou-stained smear obtained from larynx prior to intubation. Scattered squamous cells are intermingled with respiratory type epithelium. The latter cells are swollen and cilia are difficult to visualize $(\times 450)$.

Smears following extubation were similar, except that columnar cells were conspicuous. They tended to be in clumps or sheets and were well preserved. Cilia were obvious. There was no increase in neutrophils, and no fibrin was seen. There was no evidence of an inflammatory response regardless of the duration of intubation (Fig. 2).

The smears after intubation in which Xylocaine was used were the same, except that columnar cells tended to be spread singly, with less conspicuous clumps.

\section{Discussion}

The mucosa of the larynx is mainly ciliated columnar epithelium. Squamous epithelium covers the vocal folds adhering to the vocal ligament. It is also found at the entrance to the larynx covering the anterior and upper posterior surface of 


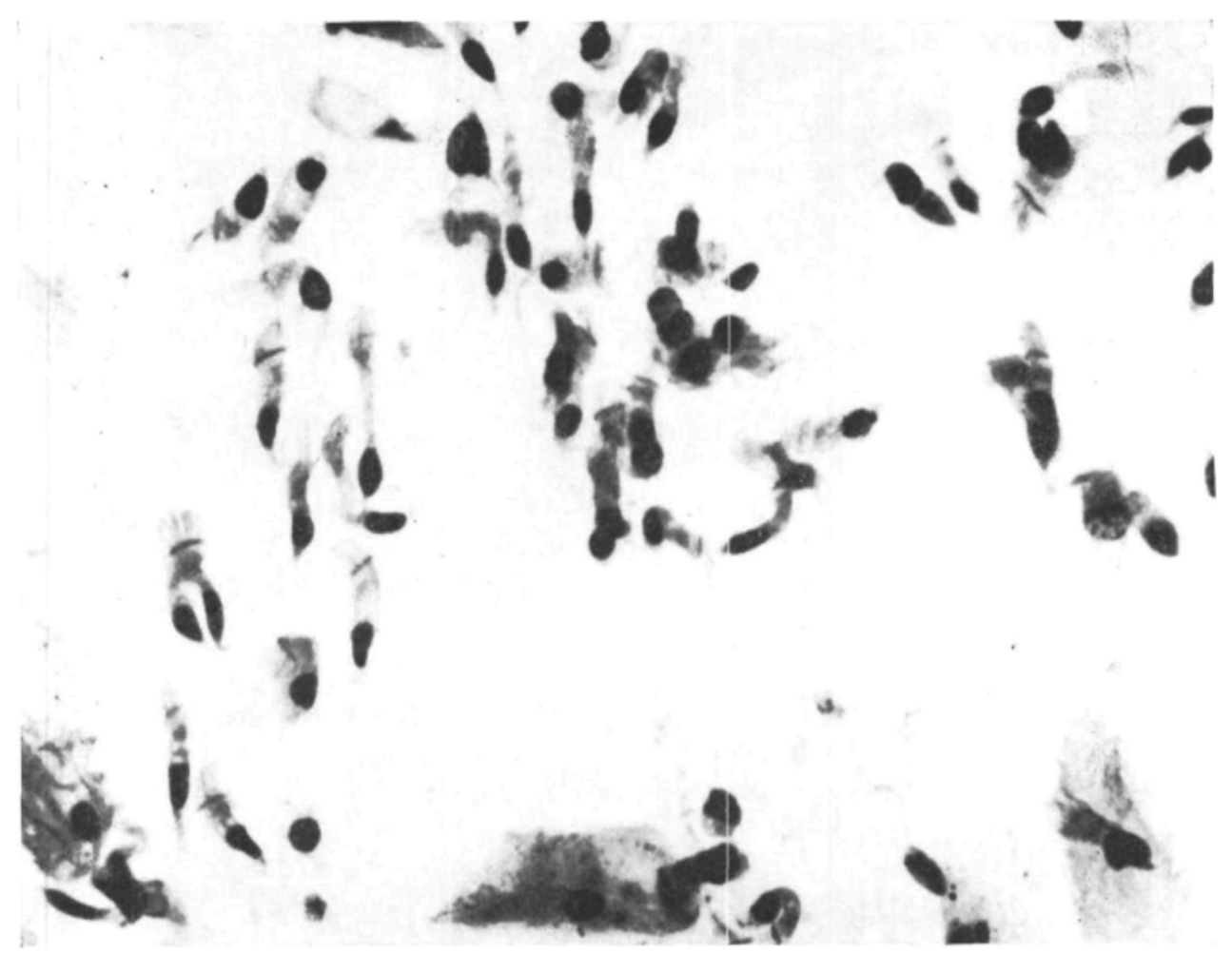

Figure 2. Papanicolaou-stained smear obtained after intubation. The predominant cell type is a slender columnar cell with distinct cilia. No red blood cells or inflammatory cells are visible $(\times 450)$.

the epiglottis and the upper portion of the aryepiglottic folds in continuity with similar epithelium of the pharynx. ${ }^{6}$

The vulnerability of the squamous mucosa of the vocal folds, particularly the mucoperichondrium in the area of the vocal process, is well established. ${ }^{7}$ Instrumentation is not necessarily the exclusive source of significant trauma related to intubation and the vocal cords. The constant activity of the cords, vocal trauma, infection, abnormal position of the head, and the size of the larynx are involved in cord lesions. ${ }^{2,8,9}$ Long-term intubation in children illustrates the combination of several of these factors. In a recently reported series, seven of twenty-nine such patients surviving their primary disease developed laryngeal stenosis. ${ }^{10}$

The fragility of respiratory epithelium is documented by Hilding and Hilding. ${ }^{11}$ The passage of gauze with moderate pressure over the surface of the trachea removed epithelium and injured the basement membrane. A single light passage of a dry swab was utilized in an effort to produce a lesser lesion. Lesions were always evident, although minimal if sufficient mucous was present to act as a lubricant. Cleavage of the epithelium was a striking finding in many specimens, and changes in the nuclei of separated columnar cells that were not detached primarily suggested subsequent sloughing. ${ }^{11}$

Disruption of the epithelial layer is usually quickly restored by the regenerative 
properties of respiratory epithelium. ${ }^{12}$ However, the occasional development of major complications following intubation demonstrates the possibility of other consequences. Way and Sooy consistently produced ulceration of the tracheal mucosa overlying the cricoid cartilage following two hours of intubation with an oversize tube in anaesthetized monkeys. ${ }^{13}$ Debility, anaemia, vitamin deficiency, oedema, infection, reduced secretions, and the respiratory movement of tissue in contact with the tube are contributing factors enumerated by Dwyer et al. They found that ulceration of the respiratory epithelium during prolonged intubation overlaid the tracheal cartilages and was not seen in intubations of less than six hours' duration. ${ }^{14}$ The frequent finding of tissue in aspirate removed by catheter suction through tracheostomies is further evidence of the susceptibility of respiratory epithelium to minimal trauma. ${ }^{15}$

In the cases presented, unintentional trauma secondary to endotracheal intubation was not prevented by reducing antecedent factors and selecting only cases in which intubation was performed without difficulty. It continued relatively unchanged when lubrication was added in the form of topical anaesthesia to the larynx, and when anaesthetic ointment was applied to the tube. The vulnerability of ciliated columnar epithelium to damage is emphasized by the predominance of such cells in the cytology following extubation. Individuals performing procedures involving respiratory epithelium must use meticulous care to avoid enhancing injury and encouraging complications.

\section{SUMMARY}

The study uses exfoliative cytology to document injury to the respiratory epithelium following endotracheal intubation in a series of 70 children. Ciliated columnar epithelial cells occurring in clumps or sheets were conspicuous following extubation as compared with smears obtained in a similar way preceding intubation. This was interpreted as evidence of unintentional trauma and indicates the vulnerability of respiratory epithelium.

\section{RÉSUMÉ}

Nous avons étudié des cytologies exfoliatrices laryngées chez 70 enfants avant et après des intubations endotrachéales de durées diverses. Nous avons fait des frottis de façon atraumatique avec un tampon de coton sec sur la région postéromédiale des cordes vocales et nous avons employé la coloration de Papanicolaou. La lame avant l'intubation était faite d'un prélèvement venant de la corde vocale droite et celle qui suivait l'intubation, d'un prélèvement de la corde vocale gauche. Nous avons exclus de l'expérience les malades qui avaient souffert récemment d'une infection des voies respiratoires hautes ou qui avaient été blessés au cours de l'intubation. Les frottis prélevés avant l'intubation ont consisté en cellules épithéliales de types squammeux et en colonnes avec des histiocytes muqueux et de rares neutrophiles. Les frottis prélevés après l'intubation ont montré la présence de cellules épithéliales ciliées en colonnes en paquets ou en lames. Aucune évidence de réponse de cellule inflammatoire en dépit de la durée de 
l'intubation. L'interprétation: évidence de traumatisme involontaire et témoignage de vulnérabilité de l'épithélium des voies respiratoires.

\section{REFERENCES}

1. Girlespie, N. A. Endotracheal Anesthesia. 3rd ed., Madison: University of Wisconsin Press (1963).

2. JACKsON, C. Contact Ulcer Granuloma and Other Laryngeal Complications of Endotracheal Anesthesia. Anesthesiology. 14: 425 (1953).

3. Wolfson, B. Minor Laryngeal Sequelae of Endotracheal Intubation. Brit. J. Anaesth. 30: 326 (1958).

4. Safar, P. Respiratory Therapy. 1st ed., Philadelphia: Davis (1965).

5. Koss, L. Diagnostic Cytology. 2nd ed., Philadelphia: Jippincott (1961).

6. ElLIs, H. Anatomy for Anesthetists. 1st ed., Philadelphia: Davis (1963).

7. Myerson, M. C. Granulomatous Polyp of the Larynx following Intratracheal Anesthesia. A.M.A. Arch. Otolaryng. 62: 182 (1955).

8. Howland, W. S. \& LEWIS, J. S. Mechanisms in the Development of Post-intubation Granulomas of the Larynx. Ann. Otol. Rhin. \& Laryng. 65: 1006 (1956).

9. Holinger, P. H. \& Johnston, K. C. Contact Ulcer of the Larynx. J.A.M.A. 172: 511 (1960).

10. Fearson, B.; MacDonald, R. E.; SMith, C.; \& Mrrchell, D. Airway Problems in Children following Prolonged Endotracheal Intubation. Ann. Otol. Rhin. \& Laryng. 75: 975 (1966).

11. Hilding, A. C. \& Hilding, J. A. Tolerance of the Respiratory Mucous Membrane to Trauma: Surgical Swabs and Intratracheal Tubes. Ann. Otol, Rhin. \& Laryng. 71: 455 (1962).

12. WILHELM, D. L. Regeneration of Tracheal Epithelium. J. Path. \& Bact. 65: 543 (1953).

13. WAY, W. L. \& SOOY, F. A. Histologic Changes Produced by Endotracheal Intubation. Ann. Otol. Rhin. \& Laryng. 74: 799 ( 1965).

14. Dwxer, C. S.; Kronnengerg, S.; \& SakLad, M. Endotracheal Tube: Consideration of Its Traumatic Effect with Suggestions for Modifications Thereof. Anaesthesiology. 10: 714 (1949).

15. Plum, F. \& Dunning, M. F. Technics for Minimizing Trauma to the Tracheobronchial Tree after Tracheotomy. New England J. Med. 254: 193 (1956). 